\title{
Poly(propylene carbonate)/exfoliated graphite nanocomposites: selective adsorbent for the extraction and detection of gold(III)
}

\author{
SHER BAHADAR KHAN ${ }^{1,2, *}$, HADI M MARWANI ${ }^{1,2}$, JONGCHUL SEO ${ }^{3}$, ESRAA M BAKHSH ${ }^{2}$, \\ KALSOOM AKHTAR ${ }^{4}$, DOWAN KIM ${ }^{3}$ and ABDULLAH M ASIRI ${ }^{1,2}$ \\ ${ }^{1}$ Center of Excellence for Advanced Materials Research (CEAMR), King Abdulaziz University, P.O. Box 80203, Jeddah \\ 21589, Saudi Arabia \\ ${ }^{2}$ Department of Chemistry, Faculty of Science, King Abdulaziz University, P.O. Box 80203, Jeddah 21589, Saudi Arabia \\ ${ }^{3}$ Department of Packaging, Yonsei University, Wonju-si, Kangwon-do 720-221, South Korea \\ ${ }^{4}$ Division of Nano Sciences and Department of Chemistry, Ewha Womans University, Seoul 120-750, South Korea
}

MS received 18 May 2014; revised 15 September 2014

\begin{abstract}
In this study, poly(propylene carbonate) (PPC) and exfoliated graphite (PPC-EG) composites were prepared by the solution blending method and their selective extraction and detection of gold(III) were investigated. Specifically, a new effective adsorbent was developed for a selective extraction and determination of gold(III) by use of inductively coupled plasma optical emission spectrometry. The selectivity of PPC (PPC-EG 0.5, PPC-EG 1, PPC-EG 2, PPC-EG 3 and PPC-EG 5) was investigated toward several metal ions, including Au(III), Cd(II), Co(II), $\mathrm{Cu}(\mathrm{II}), \mathrm{Hg}(\mathrm{II}), \mathrm{Pb}(\mathrm{II}), \mathrm{Pd}(\mathrm{II})$ and $\mathrm{Zn}(\mathrm{II})$. Based on selectivity and pH studies, Au(III) was the most quantitatively adsorbed on PPC-EG 0.5 phase at pH 2, indicating that PPC-EG 0.5 was the most selective toward Au(III) among other metal ions. The adsorption isotherm followed the Langmuir model with adsorption capacity of $157.61 \mathrm{mg} \mathrm{g}^{-1}$ of PPC-EG 0.5 for $\mathrm{Au}(\mathrm{III})$, which was in agreement with experimental data of adsorption isotherm study. The kinetic of adsorption for $\mathrm{Au}(\mathrm{III})$ was investigated by a pseudo-first- and second-order models. Results of kinetic models displayed that the adsorption of $\mathrm{Au}$ (III) on the PPC-EG 0.5 phase obeyed a pseudo-second-order kinetic model. In addition, results of thermodynamic investigation demonstrated that the adsorption mechanism of PPC-EG 0.5 toward $\mathrm{Au}($ III) was a general spontaneous process and favourable.
\end{abstract}

Keywords. Polymer-matrix nanocomposite; exfoliated graphite; Au(III); adsorption; batch method; ICP-OES.

\section{Introduction}

Global warming and environmental pollution are primarily caused by the massive release of carbon dioxide into the atmosphere. Nowadays, the incorporation of carbon dioxide into polymers has attracted a great deal of interests in academic and industrial fields to reduce greenhouse gas pollution and has been considered an alternative to overcome shortages in conventional petroleum fuel supplies. ${ }^{1}$ Among the polymeric materials that use carbon dioxide, poly(propylene carbonate) (PPC) was first synthesized by Inoue $e t a l^{2}$ via the copolymerization of carbon dioxide and propylene oxide. It is a biodegradable aliphatic polycarbonate that can be degraded to $\mathrm{H}_{2} \mathrm{O}$ and carbon dioxide in natural environment. PPC synthesis recycles carbon dioxide from the environment and has interesting chemical and physical properties such as compatibility with other materials, impact resistance, translucence and innocuousness. Such specific properties are advantageous in adhesives, solid electrolytes, barrier materials, plasticizers and new materials for biomedical and packaging applications.

\footnotetext{
*Author for correspondence (sbkhan@kau.edu.sa)
}

However, to expand the application of PPC, works should be devoted to improving the thermal, mechanical and sensing properties by blending it with other polymers, ${ }^{3}$ introducing inorganic fillers ${ }^{4}$ or chemically modifying the end groups. ${ }^{5}$ To improve the mechanical and gas barrier properties of PPC, it was combined with exfoliated graphite (EG) via a solution blending method, and resulting in highly enhanced barrier properties. ${ }^{6}$ PPC-silica hybrid films showed proficient aqueous ethanol sensing properties. ${ }^{7}$

In general, it is very important to find appropriate methods that meet a quality control for determination of metal ions. However, direct determination of metal ions using analytical methods is insufficient owing to their low concentrations and the high concentration of interfering matrix components in most real samples. Thus, an effective separation procedure is usually required prior to the determination of metal ions for sensitive, accurate and interference-free determination of metal ions. There are a wide range of treatment techniques for separation of metal ions, for example, precipitation, ${ }^{8}$ liquid-liquid extraction, ${ }^{9}$ ion-exchange, ${ }^{10}$ cloud point extraction ${ }^{11}$ and solid phase extraction (SPE). ${ }^{12,13}$ Although the solvent extraction has been widely used due to the effective extraction ability and separation selectivity, the large amount of organic solution 
strongly destroys the environment and harms human health. Among various methods, adsorption technique is doubtless the most frequently used method. As an economical and efficient method, adsorption technique has found its extensive applications to this field, in which many kinds of adsorbents are used as adsorption materials, including inorganic oxides, ${ }^{14-16}$ zeolites, ${ }^{17}$ silica, ${ }^{18-21}$ various resins,${ }^{22-25}$ biological adsorbents, ${ }^{26}$ activated carbon $^{27-29}$ and carbon nanotubes. ${ }^{30}$

In accordance, the aim of this study was to explore the analytical potential of newly synthesized PPC-EG 0.5 phase toward a selective extraction and determination of $\mathrm{Au}(\mathrm{III})$ prior to its determination by inductively coupled plasmaoptical emission spectrometry. The selectivity of PPC (PPCEG 0.5, PPC-EG 1, PPC-EG 2, PPC-EG 3 or PPC-EG 5) toward several metal ions, including $\mathrm{Au}(\mathrm{III}), \mathrm{Cd}(\mathrm{II}), \mathrm{Co}(\mathrm{II})$, $\mathrm{Cu}(\mathrm{II}), \mathrm{Hg}$ (II), $\mathrm{Pb}$ (II), $\mathrm{Pd}(\mathrm{II})$ and $\mathrm{Zn}$ (II), was studied. In addition, the effect of $\mathrm{pH}$ on the selectivity and effectiveness of PPC-EG 0.5 for adsorption of $\mathrm{Au}$ (III) was investigated. Other parameters, such as concentration and contact time effects, influencing the maximum uptake of $\mathrm{Au}(\mathrm{III})$ on the PPC-EG 0.5 phase were studied under batch techniques. Adsorption isotherm data of $\mathrm{Au}(\mathrm{III})$ adsorption on PPCEG 0.5 followed the classical adsorption isotherm of Langmuir. The kinetic analysis for adsorption process suggested that the adsorption isotherm data obeyed the pseudo-secondorder kinetic model. Finally, the thermodynamic behaviour of $\mathrm{Au}(\mathrm{III})$ adsorption on the PPC-EG 0.5 phase was investigated.

\section{Experimental}

\subsection{Chemicals and reagents}

PPC with an average molecular weight $\left(M_{\mathrm{n}}\right)$ of $180,000 \mathrm{~g} \mathrm{~mol}^{-1}$ was provided by SK Innovation Co., Ltd. (Chunan, Korea). Expandable graphite powders (EXP-527, purity >99\%) were purchased from Hyundai Coma Co., Ltd. (Youngju, Korea). Dimethyl formamide (DMF) was purchased from Duksan Chemical Co., Ltd. (Ansan, Korea). All materials in this study were used as received, without further purification. Stock standard solutions of $1000 \mathrm{mg}^{-1} \mathrm{Au}(\mathrm{III})$, $\mathrm{Cd}(\mathrm{II}), \mathrm{Co}(\mathrm{II}), \mathrm{Cu}(\mathrm{II}), \mathrm{Pb}(\mathrm{II})$ and $\mathrm{Zn}$ (II) were purchased from Sigma-Aldrich (Milwaukee, WI, USA). Mercuric nitrate $\left[\mathrm{Hg}\left(\mathrm{NO}_{3}\right)_{2}\right]$ and palladium nitrate $\left[\mathrm{Pd}\left(\mathrm{NO}_{3}\right)_{2}\right]$ were also obtained from Sigma-Aldrich. All reagents used were of analytical and spectral purity grade. Doubly distilled deionized water was used throughout experimental studies.

\subsection{Preparation of the new solid phase extractor}

In this study, exfoliated graphite (EG) was prepared by rapid heating of powder expandable graphite at $1050^{\circ} \mathrm{C}$ and subsequent ultrasonification and centrifugation, as described in our previous study. ${ }^{6}$ The PPC-EG nanocomposite films with EG loadings of $0.5-5 \mathrm{wt} \%$ were prepared as follows: PPC
(2 g) was dissolved in $30 \mathrm{ml}$ of DMF at $50^{\circ} \mathrm{C}$. EG powder were dispersed in DMF and dissolved by ultrasonication for $20 \mathrm{~min}$. To investigate the effect of EG content on the properties of the nanocomposite films, formulations with several different EG contents were prepared; 0.5, 1, 2, 3 and $5 \mathrm{wt} \%$ with respect to the PPC content. These samples depending on the PPC content were coded as PPC-EG 0.5, PPC-EG 1, PPC-EG 2, PPC-EG 3 and PPC-EG 5, respectively. The obtained homogeneous solutions were slowly dropped onto a glass plate and vacuum dried to a constant weight at $60^{\circ} \mathrm{C}$. The films were approximately $30 \mu \mathrm{m}$ thick and were peeled from the plate for additional testing.

\subsection{Adsorption method procedure}

All stock standard solutions of $\mathrm{Au}(\mathrm{III}), \mathrm{Cd}(\mathrm{II}), \mathrm{Co}(\mathrm{II})$, $\mathrm{Cu}$ (II), $\mathrm{Hg}$ (II), $\mathrm{Pb}$ (II), $\mathrm{Pd}(\mathrm{II})$ and $\mathrm{Zn}$ (II) were prepared in 18.2 $\mathrm{M} \Omega \mathrm{cm}$ distilled deionized water and stored in the dark at $4^{\circ} \mathrm{C}$. For selectivity study, standard solutions of $1 \mathrm{mg} \mathrm{l}^{-1}$ of $\mathrm{Au}(\mathrm{III})$ (or other metal ions) were prepared and individually mixed with $20 \mathrm{mg}$ PPC (PPC-EG 0.5, PPC-EG 1, PPC-EG 2, PPC-EG 3 or PPC-EG 5). In addition, standard solutions of $1 \mathrm{mg}^{-1} \mathrm{Au}(\mathrm{III})$ ion were prepared, adjusted to $\mathrm{pH}$ values ranging 1.0-9.0 with appropriate buffer solutions, $0.2 \mathrm{~mol} \mathrm{l}^{-1} \mathrm{HCl} / \mathrm{KCl}$ for $\mathrm{pH} 1.0$ and 2.0, $0.1 \mathrm{~mol} \mathrm{l}^{-1}$ $\mathrm{CH}_{3} \mathrm{COOH} / \mathrm{CH}_{3} \mathrm{COONa}$ for $\mathrm{pH} 3.0-6.0$ and $0.1 \mathrm{~mol} \mathrm{l}^{-1}$ $\mathrm{Na}_{2} \mathrm{HPO}_{4} / \mathrm{HCl}$ for $\mathrm{pH} 7.0-9.0$. Then, all standard solutions were individually mixed with $20 \mathrm{mg}$ PPC-EG 0.5 in order to study the effect of $\mathrm{pH}$ on the selectivity of PPC-EG 0.5 adsorption toward Au(III). All mixtures were mechanically shaken for $1 \mathrm{~h}$ using a mechanical shaker at $150 \mathrm{rpm}$ and room temperature. The PPC-EG 0.5 phase was then removed by filtration, and the concentration of $\mathrm{Au}(\mathrm{III})$ in the aqueous solution was determined by inductively coupled plasmaoptical emission spectrometer. For the study of adsorption capacity of $\mathrm{Au}(\mathrm{III})$ under batch conditions, standard solutions of $5,10,15,20,30,50,75,100,125,150,200$ and $250 \mathrm{mg}^{-1} \mathrm{Au}(\mathrm{III})$ were prepared as above, adjusted to the optimum $\mathrm{pH}$ value of 2.0 and individually mixed with $20 \mathrm{mg}$ PPC-EG 0.5. In addition, the effect of contact time on $\mathrm{Au}(\mathrm{III})$ uptake capacity was performed under the same batch conditions but at different equilibrium periods $(2.5,5$, $10,20,30,40,50$ and $60 \mathrm{~min})$. For thermodynamic investigation, standard solutions of $5 \mathrm{mg} \mathrm{l}^{-1} \mathrm{Au}(\mathrm{III})$ were prepared, adjusted to the $\mathrm{pH}$ value of 2.0 as above and individually mixed with $20 \mathrm{mg}$ PPC-EG 0.5 . Thermodynamic study of the adsorption of PPC-EG 0.5 toward Au(III) was also performed under the same batch conditions at different temperatures $(273,298,313,338$ and $353 \mathrm{~K})$.

\subsection{Instrumentation}

A pH meter (InoLab ${ }^{\circledR}$ pH 7200, IL, USA) was employed for the $\mathrm{pH}$ measurements with absolute accuracy limits at $\mathrm{pH}$ measurements being defined by NIST buffers. A Perkin 
Elmer inductively coupled plasma-optical emission spectrometer (ICP-OES) model Optima 4100 DV, USA was used for the determination of metal ions. The ICP-OES instrument was optimized daily before measurement and operated as recommended by the manufacturers. The ICP-OES spectrometer was used with following parameters: FR power, $1300 \mathrm{~kW}$; frequency, $27.12 \mathrm{MHz}$; demountable quartz torch, Ar/Ar/Ar; plasma gas (Ar) flow, $15.01 \mathrm{~min}^{-1}$; auxiliary gas (Ar) flow, $0.21 \mathrm{~min}^{-1}$; nebulizer gas (Ar) flow, $0.81 \mathrm{~min}^{-1}$; nebulizer pressure, 2.4 bar; glass spray chamber according to Scott (Ryton), sample pump flow rate, $1.5 \mathrm{ml} \mathrm{min}^{-1}$; integration time, $3 \mathrm{~s}$; replicates, 3; wavelength range of monochromator 165-460 nm. Concentrations of selected metal ions were determined at wavelengths of $267.60 \mathrm{~nm}$ for $\mathrm{Au}(\mathrm{III})$, $228.80 \mathrm{~nm}$ for $\mathrm{Cd}(\mathrm{II}), 230.79 \mathrm{~nm}$ for $\mathrm{Co}(\mathrm{II}), 327.39 \mathrm{~nm}$ for $\mathrm{Cu}(\mathrm{II}), 253.65 \mathrm{~nm}$ for $\mathrm{Hg}(\mathrm{II}), 220.35 \mathrm{~nm}$ for $\mathrm{Pb}(\mathrm{II})$, $340.46 \mathrm{~nm}$ for $\mathrm{Pd}(\mathrm{II})$ and $206.20 \mathrm{~nm}$ for $\mathrm{Zn}(\mathrm{II})$.

\section{Results and discussion}

\subsection{Selectivity study}

The preparation of EG and PPC-EG nanocomposite films and their physical properties were described in our previous

Table 1. Selectivity study of different phases $(20 \mathrm{mg})$ adsorption toward different metal ions at $(N=3)$.

\begin{tabular}{lccc}
\hline Phase & Metal ion & $q_{\mathrm{e}}\left(\mathrm{mg} \mathrm{g}^{-1}\right)$ & $K_{\mathrm{d}}\left(\mathrm{ml} \mathrm{g}^{-1}\right)$ \\
\hline PPC & $\mathrm{Au}(\mathrm{III})$ & 0.74 & $1.80 \times 10^{3}$ \\
PPC-EG 0.5 & $\mathrm{Au}(\mathrm{III})$ & 1.24 & $2.49 \times 10^{5}$ \\
& $\mathrm{Cd}$ (II) & 1.22 & $4.88 \times 10^{4}$ \\
& $\mathrm{Hg}(\mathrm{II})$ & 1.17 & $1.89 \times 10^{4}$ \\
& $\mathrm{Zn}$ (II) & 1.05 & $6.66 \times 10^{3}$ \\
& $\mathrm{Pd}(\mathrm{II})$ & 0.98 & $4.46 \times 10^{3}$ \\
& $\mathrm{Cu}$ (II) & 0.82 & $2.38 \times 10^{3}$ \\
& $\mathrm{~Pb}$ (II) & 0.77 & $2.01 \times 10^{3}$ \\
PPC-EG 1 & $\mathrm{Co}$ (II) & 0.76 & $1.95 \times 10^{3}$ \\
PPC-EG 2 & $\mathrm{Au}(\mathrm{III})$ & 0.78 & $2.09 \times 10^{3}$ \\
PPC-EG 3 & $\mathrm{Au}(\mathrm{III})$ & 1.22 & $5.31 \times 10^{4}$ \\
PPC-EG 5 & $\mathrm{Au}(\mathrm{III})$ & 0.69 & $1.56 \times 10^{3}$ \\
& $\mathrm{Au}(\mathrm{III})$ & 0.96 & $4.16 \times 10^{3}$ \\
\hline
\end{tabular}

study. ${ }^{6}$ Selectivity of PPC (PPC-EG 0.5, PPC-EG 1, PPCEG 2, PPC-EG 3 or PPC-EG 5) toward different metal ions was investigated based on determination of the distribution coefficient. The distribution coefficient $\left(K_{\mathrm{d}}\right)$ can be obtained from the following equation: ${ }^{31}$

$$
K_{\mathrm{d}}=\frac{\left(C_{\mathrm{o}}-C_{\mathrm{e}}\right)}{C_{\mathrm{e}}} \times \frac{V}{m},
$$

where $C_{\mathrm{o}}$ and $C_{\mathrm{e}}$ are the initial and final concentrations before and after filtration with the adsorbent, respectively, $V$ refers to the volume $(\mathrm{ml})$ and $m$ the weight of adsorbent $(\mathrm{g})$. Distribution coefficient values of all metal ions investigated in this study are illustrated in table 1 . As shown in table 1, it can be clearly observed that PPC-EG 0.5 phase has the greatest distribution coefficient value $\left(2.49 \times 10^{5} \mathrm{ml} \mathrm{g}^{-1}\right)$ toward $\mathrm{Au}(\mathrm{III})$ among all metal ions. These results indicated that the selectivity of newly synthesized PPC-EG 0.5 phase toward $\mathrm{Au}(\mathrm{III})$ was the most as compared to other metal ions investigated in this study (scheme 1). However, it can also be noted that the trend in the uptake capacity of $\mathrm{Au}(\mathrm{III})$ is not followed for PPC-EG 1 and PPC-EG 2 in table 1. This behaviour is in agreement with the saturation of binding sites of PPC-EG nanocomposite film with EG loading of $0.5 \mathrm{wt} \%$. When EG loading of nanocomposite film increased from 0.5 to $5 \mathrm{wt} \%$, fluctuations in the maximum uptake capacity of $\mathrm{Au}(\mathrm{III})$ can be expected after the saturation process.

\subsection{Effect of $p H$}

Extraction of metal ions from aqueous media by adsorption is usually $\mathrm{pH}$ dependent because $\mathrm{pH}$ affects the surface charge of adsorbent, the degree of ionization and species of adsorbate. ${ }^{32}$ In this study, the effect of $\mathrm{pH}$ on the adsorption of $\mathrm{Au}$ (III) by newly synthesized PPC-EG 0.5 phase was investigated. A concentration of $1 \mathrm{mg} \mathrm{l}^{-1} \mathrm{Au}$ (III) was chosen, and $\mathrm{pH}$ values of sample solutions were adjusted to a range from 1.0 to 9.0 with corresponding buffer solutions. All standard solutions were individually mixed with $20 \mathrm{mg}$ PPC-EG 0.5.

It can be clearly observed from figure 1 that the \% extraction is strongly dependent on the $\mathrm{pH}$ value of solution. Figure 1 depicts that there is an increase followed by a subsequent decrease in the $\%$ extraction of $\mathrm{Au}(\mathrm{III})$ with an increase
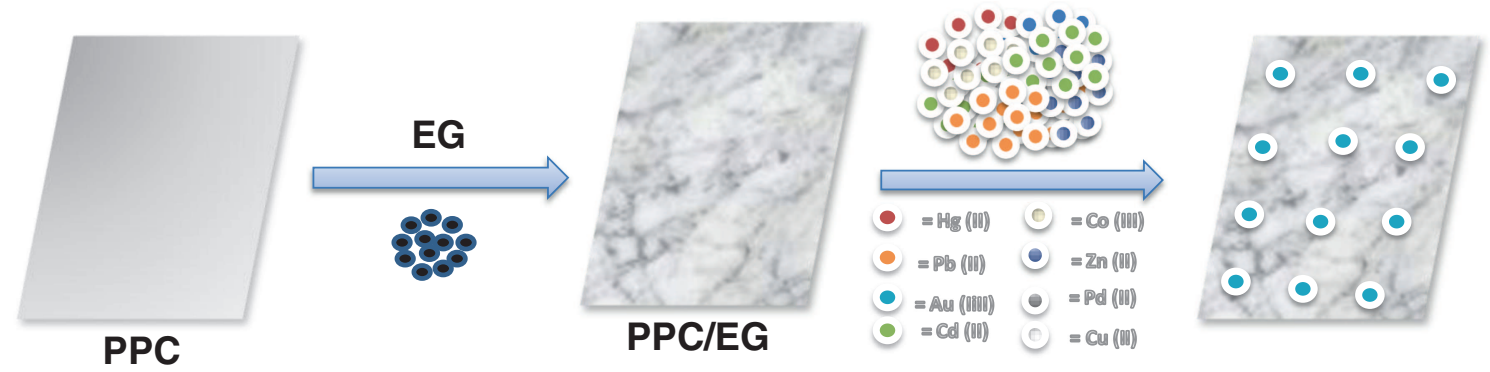

Scheme 1. Schematic view of adsorption process. 


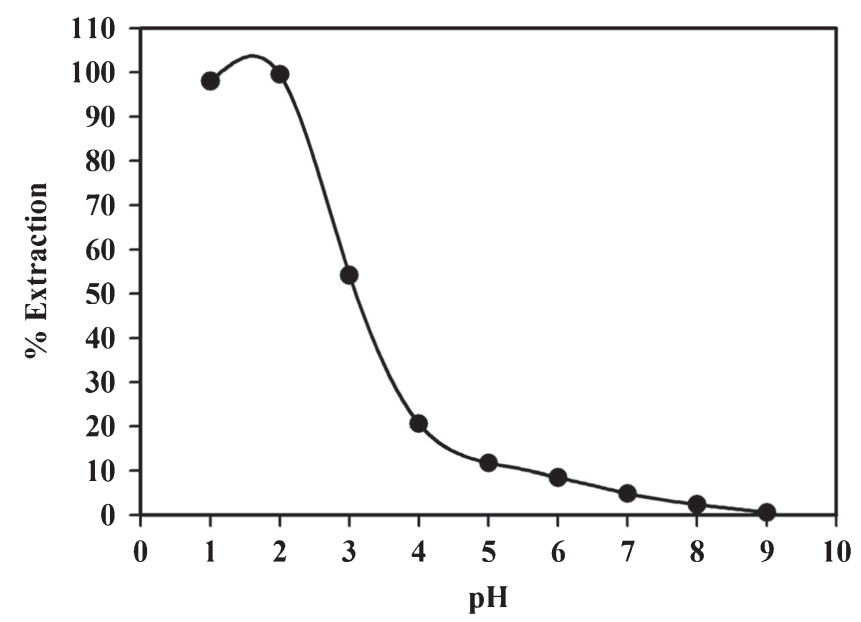

Figure 1. Effect of $\mathrm{pH}$ on the adsorption of $1 \mathrm{mg} \mathrm{l}^{-1} \mathrm{Au}$ (III) on $20 \mathrm{mg}$ PPC-EG 0.5 phase at $25^{\circ} \mathrm{C}$.

of the $\mathrm{pH}$ value from 1.0 up to 9.0. However, it is motivating to notice that the \% extraction of $\mathrm{Au}(\mathrm{III})$ was reached to the highest $(99.52 \%)$ at $\mathrm{pH} 2.0$, providing that the PPC-EG 0.5 phase was most selective toward $\mathrm{Au}(\mathrm{III})$ at this $\mathrm{pH}$ value.

The highest percentage of $\mathrm{Au}(\mathrm{III})$ extraction and selectivity with PPC-EG 0.5 phase can be attributed to the electrostatic interaction between protonated sites, presented on carbonyl groups and their two flanked alkoxy groups of PPC-EG 0.5 at $\mathrm{pH} 2.0$, and negatively charged species $\left(\mathrm{AuCl}_{4}{ }^{-}\right)$, the primary form of $\mathrm{Au}(\mathrm{III})$ in $\mathrm{HCl}$ solution. Thus, it makes possible to selectively separate $\mathrm{Au}(\mathrm{III})$ from the matrix. On the basis of the above results, the optimum $\mathrm{pH}$ value of 2.0 was selected to be the optimum for the study of other parameters controlling its maximum uptake on PPC-EG 0.5 under static conditions.

\subsection{Determination of adsorption capacity}

Adsorption capacity is the maximum metal quantity taken up by $1 \mathrm{~g}$ of solid phase and given by $\mathrm{mg}$ metal $\mathrm{g}^{-1}$. In this study, the uptake capacity of $\mathrm{Au}$ (III) was investigated by varying amounts of $\mathrm{Au}(\mathrm{III})$ and individually mixing them with $20 \mathrm{mg}$ PPC-EG 0.5 at $\mathrm{pH} 2.0$ under batch procedure.

From adsorption isotherm study, the adsorption capacity of PPC-EG 0.5 for $\mathrm{Au}$ (III) was determined to be $155.71 \mathrm{mg} \mathrm{g}^{-1}$ (figure 2), which is higher than those previously reported the adsorption capacity of $\mathrm{Au}(\mathrm{III})$ with other adsorbents $\left(12.30,{ }^{33} 14.80,{ }^{34} 33.57,33.57,{ }^{35} 57.0^{36,37}\right.$ and $72.01^{38,39}$ $\mathrm{mg} \mathrm{g}^{-1}$ ). From figure 2, it can also be observed that there is a minimal decrease in the uptake capacity of PPC-EG 0.5 for $\mathrm{Au}$ (III) after saturation. This behaviour is consistent with the saturation of binding sites of PPC-EG 0.5 with $\mathrm{AuCl}_{4}{ }^{-}$ species, in particular at the highest concentration of $\mathrm{Au}(\mathrm{III})$, $250 \mathrm{mg}^{-1}$. Thus, minimal to no effect of concentration may be noted in the maximum uptake capacity of PPC-EG 0.5 for $\mathrm{Au}(\mathrm{III})$ after this saturation process.

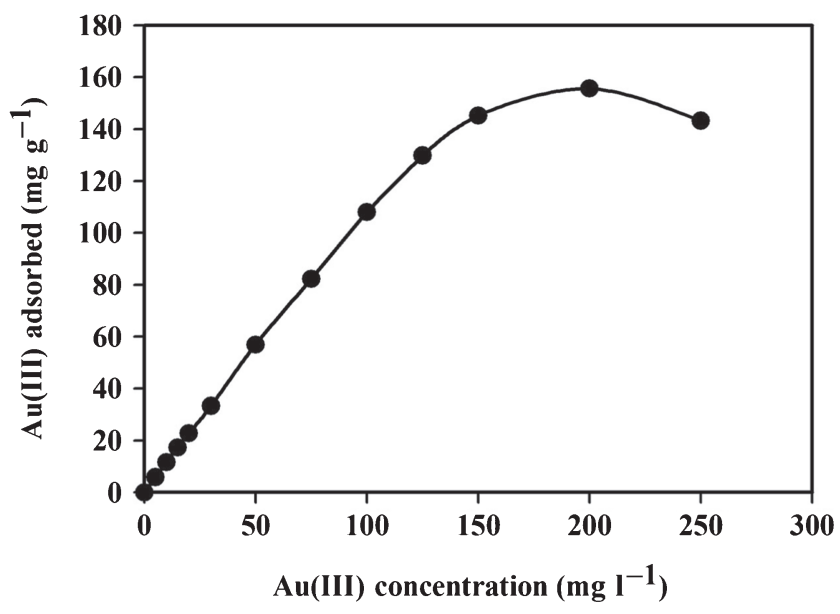

Figure 2. Adsorption profile of $\mathrm{Au}(\mathrm{III})$ on $20 \mathrm{mg}$ PPC-EG $0.5 \mathrm{in}$ relation to the concentration at $\mathrm{pH} 2.0$ and $25^{\circ} \mathrm{C}$.

\subsection{Adsorption isotherm models}

It is very important to study adsorption isotherm models in order to develop an equation that accurately represents the results. Both Langmuir and Freundlich adsorption isotherm models ${ }^{37,38}$ were used to interpret equilibrium isotherm data. In this study, experimental data were well correlated to Langmuir equation. The Langmuir isotherm model is based upon an assumption of monolayer adsorption onto a surface containing a finite number of adsorption sites of uniform energies of adsorption with no transmigration of adsorbate in the plane of the surface. The Langmuir classical adsorption isotherm can be expressed as follows: ${ }^{39}$

$$
C_{\mathrm{e}} / q_{\mathrm{e}}=\left(C_{\mathrm{e}} / Q_{\mathrm{o}}\right)+1 / Q_{\mathrm{o}} b,
$$

where $C_{\mathrm{e}}$ is the concentration of metal ion in solution at equilibrium $\left(\mathrm{mg} \mathrm{ml}^{-1}\right)$, and $q_{\mathrm{e}}$ represents the amount of metal ion per gram of the adsorbent at equilibrium $\left(\mathrm{mg} \mathrm{g}^{-1}\right)$. The symbols $Q_{\mathrm{o}}$ and $b$ refer to Langmuir constants for PPC-EG 0.5 and are related to the maximum $\mathrm{Au}(\mathrm{III})$ adsorption capacity $\left(\mathrm{mg} \mathrm{g}^{-1}\right)$ and affinity parameter $\left(\mathrm{mg}^{-1}\right)$, respectively. Langmuir constants $Q_{\mathrm{o}}$ and $b$ can be calculated from a linear plot of $C_{\mathrm{e}} / q_{\mathrm{e}}$ against $C_{\mathrm{e}}$ with a slope and intercept equal to $1 / Q_{\mathrm{o}}$ and $1 / Q_{\mathrm{o}} b$, respectively. Moreover, essential characteristics of the Langmuir adsorption isotherm model can be obtained in terms of a dimensionless constant separation factor or equilibrium parameter, $R_{\mathrm{L}}$, which is defined as follows:

$$
R_{\mathrm{L}}=\frac{1}{\left(1+b C_{\mathrm{o}}\right)},
$$

where $b$ is the Langmuir constant, indicating the nature of adsorption and shape of isotherm, and $C_{\mathrm{o}}$ denotes the initial concentration of $\mathrm{Au}(\mathrm{III})$. The value of $R_{\mathrm{L}}$ describes the nature of the adsorption isotherm, and $R_{\mathrm{L}}$ values between 0 and 1 represent a favourable adsorption. ${ }^{40}$

A linear plot was obtained from Langmuir isotherm equation based on the least-squares fit, confirming the validity 
of the Langmuir adsorption isotherm model for the adsorption process (figure 3 ). On the basis of the above results, one can conclude that the adsorption process was mainly monolayer on a homogeneous PPC-EG 0.5 surface. Calculated Langmuir constants $Q_{\mathrm{o}}$ and $b$ are determined to be $157.61 \mathrm{mg} \mathrm{g}^{-1}$ and $0.131 \mathrm{mg}^{-1}$, respectively. The correlation coefficient $\left(R^{2}\right)$ obtained from the Langmuir model is found to be 0.99 for adsorption of $\mathrm{Au}(\mathrm{III})$ on PPC-EG 0.5, further providing that the data were well fit with the Langmuir model. The $R_{\mathrm{L}}$ value of $\mathrm{Au}(\mathrm{III})$ adsorption on PPC-EG 0.5 is 0.04 , supporting a highly favourable adsorption process based on the Langmuir model. It is also of interest to observe that the $\mathrm{Au}(\mathrm{III})$ adsorption capacity $\left(157.61 \mathrm{mg} \mathrm{g}^{-1}\right.$ ) calculated from Langmuir equation was strongly in agreement with that ( $155.71 \mathrm{mg} \mathrm{g}^{-1}$ ) experimentally obtained from the adsorption isotherm study.

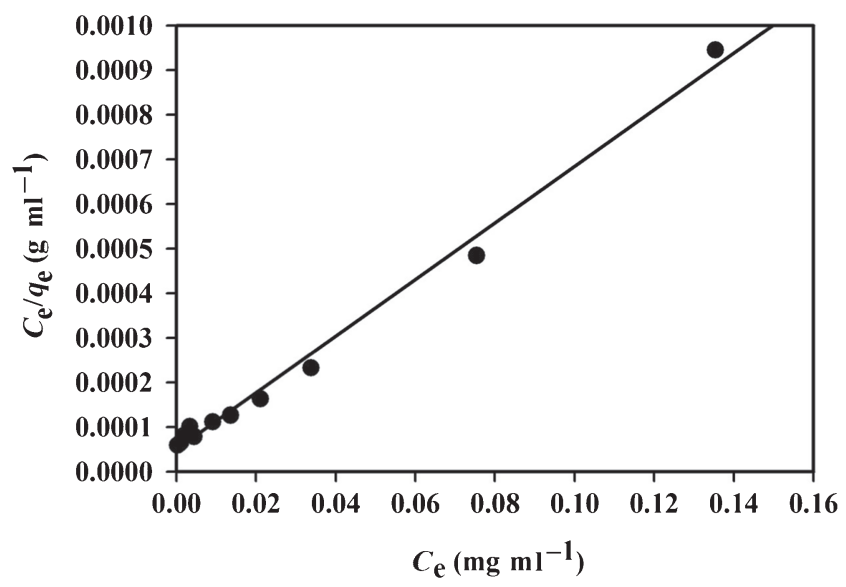

Figure 3. Langmuir adsorption isotherm model of $\mathrm{Au}(\mathrm{III})$ adsorption on $20 \mathrm{mg}$ PPC-EG 0.5 at $\mathrm{pH} 2.0$ and $25^{\circ} \mathrm{C}$. Adsorption experiments were obtained at different concentrations $\left(5-250 \mathrm{mg} \mathrm{l}^{-1}\right)$ of $\mathrm{Au}(\mathrm{III})$ under batch conditions.

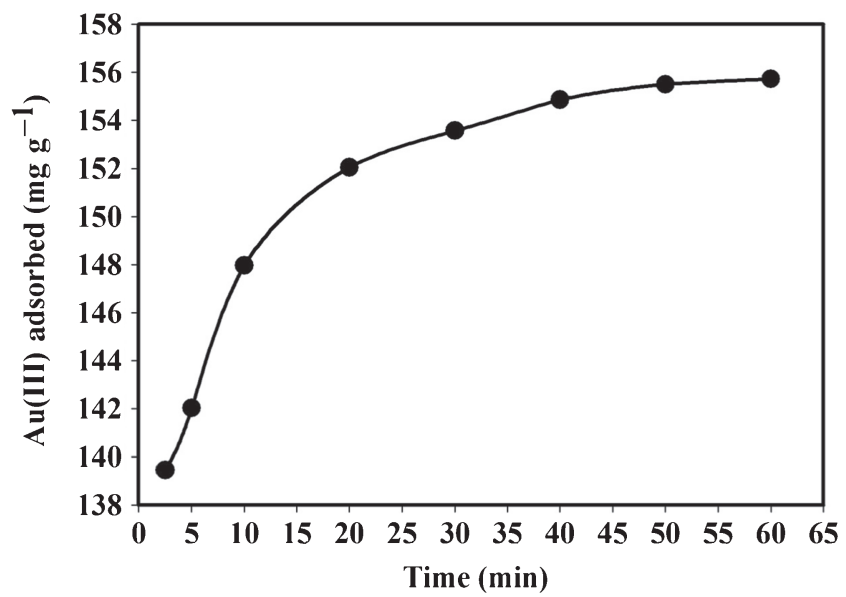

Figure 4. Effect of contact time on the adsorption of $200 \mathrm{mg} \mathrm{l}^{-1}$ $\mathrm{Au}$ (III) on $20 \mathrm{mg}$ PPC-EG 0.5 at $\mathrm{pH} 2.0$ and $25^{\circ} \mathrm{C}$.

\subsection{Effect of contact time}

The effect of shaking time on the \% extraction of $\mathrm{Au}(\mathrm{III})$ is a significant factor for determining the possible discrimination order in the behaviour of PPC-EG 0.5 adsorption toward $\mathrm{Au}(\mathrm{III})$ and estimating the time required to attain equilibrium. In this study, different contact times ranging from 2.5 to $60.0 \mathrm{~min}$ were investigated at the concentration of $200 \mathrm{mg}^{-1}$ $\mathrm{Au}(\mathrm{III})$ (figure 4). As displayed in figure 4, the amount of $\mathrm{Au}$ (III) adsorbed onto PPC-EG 0.5 phase dramatically increased with an increase of the contact time, indicating that PPC-EG 0.5 had rapid adsorption kinetics for $\mathrm{Au}(\mathrm{III})$. It can be clearly observed from figure 4 that over $147 \mathrm{mg} \mathrm{g}^{-1}$ $\mathrm{Au}(\mathrm{III})$ was adsorbed on the PPC-EG 0.5 phase after only 10 min of the equilibrium periods. The amount of $\mathrm{Au}(\mathrm{III})$ adsorbed was also raised up to more than $153 \mathrm{mg} \mathrm{g}^{-1}$ after 30 min until the maximum adsorption of PPC-EG 0.5 for $\mathrm{Au}$ (III) was reached to $155.71 \mathrm{mg} \mathrm{g}^{-1}$ after $60 \mathrm{~min}$.

\subsection{Kinetic study}

The effect of concentration on reaction rates is very essential in understanding the reaction mechanism. The adsorption kinetic data of $\mathrm{Au}(\mathrm{III})$ adsorption on PPC-EG 0.5 were investigated in terms of different kinetic models ${ }^{41}$ in order to quantify changes in adsorption with time and evaluate kinetic parameters. Kinetic models were used for goodness of fit for the experimental data using the correlation coefficient $\left(R^{2}\right)$ as a measure of agreement between the experimental data.

The pseudo-second order model is based on the assumption that the rate limiting step may be chemical adsorption involving valence forces through sharing or exchanging of electrons between the adsorbent and adsorbate. ${ }^{42}$ The pseudo-second-order equation can be written as follows:

$$
t / q_{\mathrm{t}}=1 / v_{\mathrm{o}}+\left(1 / q_{\mathrm{e}}\right) t,
$$

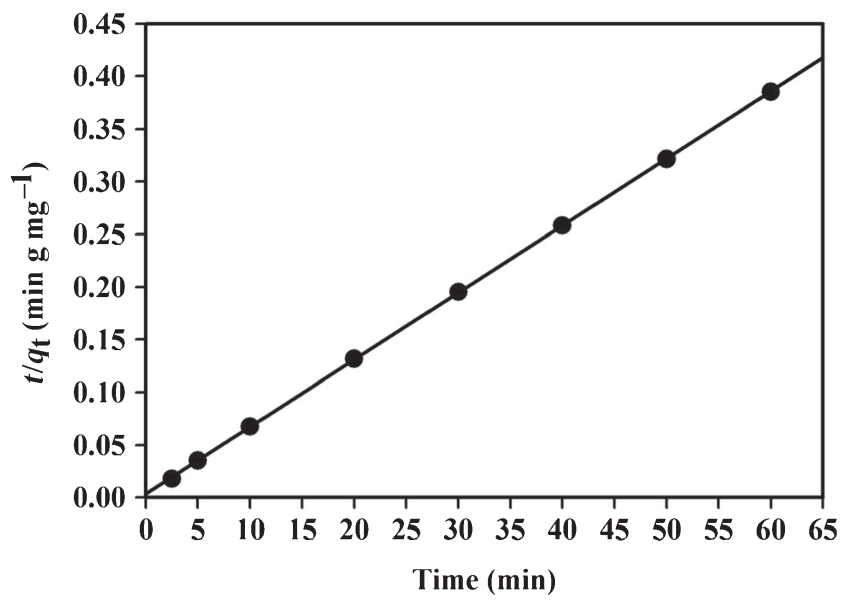

Figure 5. Pseudo-second-order adsorption kinetic model of $\mathrm{Au}(\mathrm{III})$ uptake on $20 \mathrm{mg}$ PPC-EG 0.5 at $\mathrm{pH} 2.0$ and $25^{\circ} \mathrm{C}$. 
Table 2. Calculated thermodynamic parameters of $5 \mathrm{mg} \mathrm{l}^{-1} \mathrm{Au}(\mathrm{III})$ adsorption on $20 \mathrm{mg}$ PPC-EG $0.5(N=3)$.

\begin{tabular}{lcccccc}
\hline & & \multicolumn{3}{c}{$\Delta G^{\circ}\left(\mathrm{kJ} \mathrm{mol}^{-1}\right)$} \\
\cline { 3 - 6 }$\left(H^{\circ}\left(\mathrm{kJ} \mathrm{mol}^{-1}\right)\right.$ & $\Delta S^{\circ}\left(\mathrm{J} \mathrm{mol}^{-1} \mathrm{~K}^{-1}\right)$ & $T=273 \mathrm{~K}$ & $T=298 \mathrm{~K}$ & $T=313 \mathrm{~K}$ & $T=338 \mathrm{~K}$ & $T=353 \mathrm{~K}$ \\
\hline-12.66 & 38.58 & -23.22 & -24.14 & -24.64 & -25.86 & -26.20 \\
\hline
\end{tabular}

where $v_{\mathrm{o}}=k_{2} q_{\mathrm{e}}^{2}$ denotes the initial adsorption rate $\left(\mathrm{mg} \mathrm{g}^{-1}\right.$ $\left.\min ^{-1}\right)$, and $k_{2}\left(\mathrm{~g} \mathrm{mg}^{-1} \mathrm{~min}^{-1}\right)$ corresponds to the rate constant of adsorption, $q_{\mathrm{e}}\left(\mathrm{mg} \mathrm{g}^{-1}\right)$ refers to the amount of metal ion adsorbed at equilibrium, and $q_{\mathrm{t}}\left(\mathrm{mg} \mathrm{g}^{-1}\right)$ is to the amount of metal ion on the surface of adsorbent at any time $t(\mathrm{~min})$. The parameters $q_{\mathrm{e}}$ and $v_{\mathrm{o}}$ can be easily obtained from the slope and intercept, respectively, of a plot of $t / q_{\mathrm{t}} v s$. $t$ (figure 5). It is interesting to note that adsorption kinetics data were well fit with the second-order kinetic model. The correlation coefficient $\left(R^{2}\right)$ factor was found to be 0.99 , indicating the reliability and accuracy of the pseudo-second-order adsorption. The parameters $q_{\mathrm{e}}, v_{\mathrm{o}}$ and $k_{2}$ were determined to be $156.92 \mathrm{mg} \mathrm{g}^{-1}, 299.09 \mathrm{mg} \mathrm{g}^{-1}$ $\min ^{-1}$ and $0.01 \mathrm{~g} \mathrm{mg}^{-1} \mathrm{~min}^{-1}$. The adsorption capacity of $\mathrm{Au}(\mathrm{III})$ on PPC-EG 0.5 estimated from the pseudo-secondorder kinetic model (156.92 $\mathrm{mg} \mathrm{g}^{-1}$ ) was also in good agreement with adsorption capacities obtained from both adsorption isotherm experiments $\left(155.71 \mathrm{mg} \mathrm{g}^{-1}\right)$ and Langmuir isotherm model $\left(157.61 \mathrm{mg} \mathrm{g}^{-1}\right)$, confirming the highest applicability of the pseudo-second-order nature of the adsorption of $\mathrm{Au}(\mathrm{III})$ on PPC-EG 0.5.

\subsection{Thermodynamic study}

The study of thermodynamic parameters provides a deeper mechanistic understanding of the adsorption of $\mathrm{Au}(\mathrm{III})$ on PPC-EG 0.5. Therefore, the effect of temperature on the adsorption of $20 \mathrm{mg}$ PPC-EG 0.5 for $5 \mathrm{mg}^{-1} \mathrm{Au}(\mathrm{III})$ was investigated at different temperatures $(273,298,313$, 338 and $353 \mathrm{~K})$. The distribution adsorption coefficient $\left(K_{\mathrm{d}}\right)$ corresponding to the character of a metal ion adsorbed by an adsorbent $\left(\mathrm{ml} \mathrm{g}^{-1}\right)$ can be obtained from equation (1). In addition, thermodynamic parameters of the standard enthalpy change $\left(\Delta H^{\circ}, \mathrm{kJ} \mathrm{mol}^{-1}\right)$ and standard entropy change $\left(\Delta S^{\circ}, \mathrm{J} \mathrm{mol}^{-1} \mathrm{~K}^{-1}\right)$ were determined, as summarized in table 2, from the slope and intercept, respectively, of the linear variation of $\ln K_{\mathrm{d}}$ with the reciprocal of temperature $(1 / T)$ as follows:

$$
\ln K_{\mathrm{d}}=\Delta S^{\circ} / R-\left(\Delta H^{\circ} / R T\right),
$$

where $R$ denotes the universal gas constant $\left(8.314 \mathrm{~J} \mathrm{~mol}^{-1}\right.$ $\mathrm{K}^{-1}$ ), and $T$ represents the temperature in Kelvin. The standard Gibbs free energy change $\left(\Delta G^{\circ}, \mathrm{kJ} \mathrm{mol}^{-1}\right)$ reported in table 2 was calculated from the following equation:

$$
\Delta G^{\circ}=\Delta H^{\circ}-T \Delta S^{\circ} .
$$

As can be depicted from table 2, calculated values of standard enthalpy change $\Delta H^{\circ}$ and Gibbs free energy change
$\Delta G^{\circ}$ are negative, while that of the standard entropy change $\Delta S^{\circ}$ is positive. The observed negative $\Delta H^{\circ}$ value suggested an exothermic adsorption of $\mathrm{Au}(\mathrm{III})$ on PPC-EG 0.5. In addition, the adsorption mechanism of PPC-EG 0.5 toward $\mathrm{Au}(\mathrm{III})$ is considered to be a general spontaneous process and thermodynamically favourable because of the negative $\Delta G^{\circ}$ together with positive $\Delta S^{\circ}$. The positive value of $\Delta S^{\circ}$ also provides that the degree of freedom increases at the solidliquid interface during the adsorption of $\mathrm{Au}(\mathrm{III})$ on PPCEG 0.5 . These results strongly supported the data obtained from adsorption isotherm experiments, Langmuir and kinetic adsorption isotherm models.

\section{Conclusion}

To investigate the feasibility of PPC to apply for the selective extraction and detection of Gold(III), a series of PPCEG nanocomposite films were prepared by solution blending PPC and EG prepared by rapid thermal heating. The proposed method based on the newly synthesized PPC-EG 0.5 phase not only had the efficiency toward a selective adsorption of $\mathrm{Au}$ (III) but also provided high uptake capacity of $\mathrm{Au}(\mathrm{III})$. Results obtained from adsorption isotherm models displayed that the Langmuir adsorption isotherm model was best described the Au(III) adsorption on PPC-EG 0.5. Kinetic isotherm results demonstrated that the adsorption of PPC-EG 0.5 toward Au(III) obeyed a pseudo-secondorder kinetic reaction. Based on thermodynamic study, the adsorption mechanism of $\mathrm{Au}(\mathrm{III})$ adsorption on PPC-EG 0.5 was a general spontaneous process and thermodynamically favourable. Moreover, the adsorption process is found to be exothermic in nature. This method can be an effective approach in providing a selective separation and determination of $\mathrm{Au}(\mathrm{III})$ from the complex matrices.

\section{Acknowledgements}

This project was funded by the Center of Excellence for Advanced Materials Research (CEAMR), King Abdulaziz University, Jeddah, under Grant no. CEAMR-SG-7-435.

\section{References}

1. Wang S J, Du L C, Zhao X S and Tjong S C 2002 J. Appl. Polym. Sci. 852327

2. Inoue S and Tsuruta T 1975 Appl. Polym. Symp. 26257

3. Ma X, Chang P R, Yu J and Wang N 2008 Carbohydr. Polym. 71229 
4. Shi X and Gan Z 2007 Eur. Polym. J. 434852

5. Peng S, An Y, Chen C, Fei B, Zhuang Y and Dong L 2003 Polym. Degrad. Stab. 80141

6. Lee Y, Kim D, Seo J, Han H and Khan S B 2013 Polym. Int. 62 1386

7. Khan S B, Rahman M M, Akhtar K, Asiri A M, Seo J, Han H and Alamry K 2012 Int. J. Electrochem. Sci. 74030

8. Souza A L, Lemos S G and Oliveira P V 2011 Spectrochim. Acta Part B 66383

9. Nasu A, Yamaguchi S and Sekine T 1997 Anal. Sci. 13903

10. Hershey J W and Keliher P N 1989 Spectrochim. Acta Part B 44329

11. Manzoori J L, Abdolmohammad-Zadeh H and Amjadi M 2007 Microchim. Acta 15971

12. Ahmed S A 2008 J. Hazard. Mater. 156521

13. Alvarez A M, Alvarez J R E and Alvarez R P 2007 J. Radioanal. Nucl. Chem. 273427

14. Rauf M A, Hussain M T and Hasany S M 1993 Sep. Sci. Technol. 282237

15. Hang Y, Qin Y, Jiang Z and Hu B 2003 Chem. J. Chin. Univ. 241980

16. Liang P, Cao J, Liu R and Liu Y 2007 Microchim. Acta 159 35

17. Pasinli T, Eroglu A E and Shahwan T 2005 Anal. Chim. Acta 54742

18. Mashhadizadeh M H, Pesteh M, Talakesh M, Sheikhshoaie I and Mazloum M 2008 Spectrochim. Acta Part B 63885

19. Zhang A, Wei Y and Kumagai M 2007 Sep. Sci. Technol. 42 2235

20. Liang P and Fa W 2005 Microchim. Acta 15015

21. Jia Q, Kong X, Zhou W and Bi L 2008 Microchem. J. 8982

22. Kim J S, Han C, Wee J H and Kim J S 2006 Talanta 68963

23. Jain V K, Handa A, Sait S S, Shrivastav P and Agrawal Y K 2001 Anal. Chim. Acta 429237
24. Jelinek L, Wei Y, Arai T and Kumagai M 2007 Solvent Extr. Ion Exch. 25503

25. Dave S R, Kaur H and Menon S K 2010 React. Funct. Polym. 70692

26. Diniz V and Volesky B 2005 Water Res. 39239

27. Jankowski K, Yao J, Kasiura K, Jackowska A and Sieradzka A 2005 Spectrochim. Acta Part B 60369

28. Marwani H M, Albishri H M, Soliman E M and Jalal T A 2012 J. Disp. Sci. Technol. 33549

29. Marwani H M, Albishri H M, Jalal T A and Soliman E M 2012 Desalin. Water Treat. 45128

30. Biparva P and Hadjmohammadi M R 2011 Clean: Soil, Air, Water 391081

31. Han D M, Fang G Z and Yan X P 2005 J. Chromatogr. A 1100 131

32. Zhang L, Chang X, Zhai Y, He Q, Huang X, Hu Z and Jiang $\mathrm{N}$ 2008 Anal. Chim. Acta 62984

33. Senturk H B, Gundogdua A, Bulut V N, Duran C, Soylak M, Elci L and Tufekci M 2007 J. Hazard. Mater. 149317

34. Liang P, Zhao E, Ding Q and Du D 2008 Spectrochim. Acta Part B 63714

35. Albishri H M and Marwani H M 2011 Arab. J. Chem., doi: 10.1016/j.arabjc.2011.03.017, in press

36. Rahman M M, Khan S B, Marwani H M, Asiri A M, Alamry K A and Al-Youbi A O 2013 Talanta 10475

37. Mckay G 1984 Chem. Eng. Sci. 39129

38. Ho Y S, Wase D A J and Forster C F 1996 Environ. Technol. 1771

39. Langmuir I 1916 J. Am. Chem. Soc. 382221

40. Mckay G, Blair H S and Gardener J R 1982 J. Appl. Polym. Sci. 273043

41. Rao M M, Kumar Reddy D H K, Venkateswarlu P and Seshaiah K J 2009 Environ. Manag. 90634

42. Ho Y S and Mckay G 2000 Water Res. 34735 